\title{
Indications to surgical treatment in varicose veins
}

\author{
G Roscitano*, A Cotroneo \\ From de Senectute: Age and Health Forum \\ Catanzaro, Italy. 5-7 December 2009
}

There isn't a consensus to the treatment of varicose veins because we don't have randomized controlled trials [1].

Indication to the treatment is based on different criteria: etiological, clinical and diagnostic. The treatments include: conservative therapy, sclerotherapy, phlebectomy, endovenous laser therapy, radiofrequency ablation, and surgery involving saphenous ligation and stripping [2].

Short-term advantages appeared to be associated with sclerotherapy and endovenous treatments, and longterm effectiveness was more apparent following surgical intervention. Evidence suggests conservative therapy is less effective than sclerotherapy and surgery for the treatment of varicose veins. Ligation with stripping plus phlebectomy is generally regarded as the "gold standard" for treating primary long saphenous veins. Sclerotherapy and surgery both appear to have a place in the management of varicose veins. Sclerotherapy and phlebectomy may also be more appropriate in patients with minor superficial varicose veins not related to reflux of the saphenous system or as a post- or adjunctive treatment to other procedures, such as surgery. Current evidence suggests endovenous laser therapy and radiofrequency ablation are as safe and effective as surgery, particularly in the treatment of saphenous veins. Most importantly, the type of varicose vein should govern the intervention of choice, with no single treatment universally employed [2].

\section{Conclusions}

The indications are in evolution. It is very important to use a duplex scan before the treatment. The results of the laser at 3 years and of the radiofrequency at 5 years are similar at surgery but the techniques are less invasive. In the future, sclerotherapy can be better that surgery in particular cases [3].

Department of Cardiovascular Surgery, Sant'Anna Hospital, Catanzaro, Italy
Published: 19 May 2010

\section{References}

1. Guyatt $G$, et al: Grading strength of recommendations and quality of evidence in clinical guidelines report from an American college of chest physicians task force Chest. 2006, 129:174-81.

2. Leopardi D, et al: Systematic review of treatments for varicose veins Ann Vasc Surg. 2009, 23(2):264-76.

3. Perrin M: Chirurgie à ciel ouvert de l'insuffisance veineuse superficielle EMC Tecniques Chirurgicales -Chirurgie Vasculaire., 43-161-B: 12p.

doi:10.1186/1471-2318-10-S1-L16

Cite this article as: Roscitano and Cotroneo: Indications to surgical treatment in varicose veins. BMC Geriatrics 2010 10(Suppl 1):L16.
Submit your next manuscript to BioMed Central and take full advantage of:

- Convenient online submission

- Thorough peer review

- No space constraints or color figure charges

- Immediate publication on acceptance

- Inclusion in PubMed, CAS, Scopus and Google Scholar

- Research which is freely available for redistribution

Submit your manuscript at www.biomedcentral.com/submit
C Biomed Central 